\title{
Shaped by familiarity: Memory, Space and Materiality at Imperial War Museum North.
}

\author{
Angela Loxham*
}

\begin{abstract}
This paper considers Imperial War Museum North's attempts to disturb popular memories about British experiences of war through the mobilisation of space and materiality. However, it is argued that this does not succeed because of the spatial mediation and object placement employed throughout which allow the museum to reinforce bodily, spatial and historical experiences of the outside world. The second part of the paper analyses the neglected place of the museum shop in this, which contributes to making the IWM visit one of familiarity because of the quotidian consumption practices that are encouraged there.
\end{abstract}

Key words: military museums, affect, atmosphere, consumerism, habitus, memory.

\section{Introduction}

2014 marked the centenary of the start of World War One, and 70 years have passed following the end of World War Two. Since then, European countries have been forced to consider their pasts, most notably in perpetrator nations such as Germany (Niven 2006, Moeller 2003, Herf 1997). However, critical reflections on this period have been largely avoided in the British popular imagination where beliefs regarding Britain's military roles have evolved little. Analysing this in terms of a 'usable past', Noakes argues that images of victory and unity have taken precedence over death and destruction in order to create strong ideals of nationhood (Noakes 1998). In this sense, war has been used to contribute to Anderson's notion of an imagined community with a shared, glorious past being drawn upon to create an optimistic future (Anderson 1998).

World War Two in particular is looked upon as Britain's 'good' war, during which the people came together for the nation (Connelly 2004). Despite attempts by historians to generate a more critical approach to this period (Calder 1992, Harman 1980, Harrisson 1976), the influence of the historian over popular memory is limited. This is because memories are transmitted by multiple media which promote certain ways of thinking about the past (Smith 2000). In the context of Britain and war, these are often positive. Visual material has played an important role in this and Kuhn argues that photographs show what is important to remember (Kuhn, 2002). Likewise, Barthes argues for the power of the photograph to verify (Barthes 1993). Yet with the passage of the twentieth century, feature films have come to possess a powerful inscribing effect, shaping images of war so that the stories told come to stand for reality. Such images often concern bravery and heroism at the expense of senseless destruction.

Language is also influential in the shaping of such memories. In newspapers, terms associated with World War Two are so frequently dropped into stories to describe feelings and events that familiar terms have come to stand for whole contemporary concepts. For example, the Daily Mail's reporting of Ryanair's treatment of its passengers led it to hail the 'Dunkirk Spirit', demonstrated in the face of 'Gestapo'-like staff (Daily Mail 2012). Nor is such language limited to the tabloid press; at the beginning of 2009, Gordon Brown called on British people to draw on the same spirit that got them through World War Two to face troubled economic times (The Observer 2012). The use of these ideas is subtle yet, through repetition, they encourage certain characterisations of Britain's military past. Both visual and linguistic tools contribute to what Michael Billig terms 'banal nationalism' whereby identities and memories are potently 
formed, not by metaphorical flag 'waving', but by those that 'hang'. Particular references to the nation and identity form a constant presence that are regularly encountered by the body, and thereby exert a strong influence on sensibilities concerning the past and present (Billig 1995).

These considerations have implications for the work of museums. As the reach of popular culture is so wide, subjects are not blank slates on which new memories can be written. While museums have always been endowed with authority (Bennett 1995), they are now just one among many media helping to shape memories. Yet in addition, museums no longer exist solely to educate, but must generate income and meet visitor targets. British museums dealing with war must additionally confront visitors who frequently possess fond ideas of the past. The wider impact of banal nationalism can create a problem for these museums because existing memories can create powerful and enduring ideas of the nation and its past. While not necessarily negative, these ideas can be dangerous as they can lead to an uncritical and oversimplified understanding of the present, for example in the parallels drawn between World War Two and contemporary military circumstances, as happened during the Falklands War (Billig 1995). While still bearing in mind other considerations, museums, in particular those receiving state funding, do therefore have a responsibility to promote a balanced and critical approach to the idea of nationhood and, in this instance, Britain's military past.

Museums must also consider not only the effect of images and language on memory, but also the contribution of space and objects. Paul Connerton argues that a potent way in which memories are formed is through bodily performance, most specifically in ceremonies involving repeated, spatially situated actions which inscribe socially homogenous memories (Connerton 1999). Connerton's examination of the role of performance introduces bodily participation into memory formation. However the ability of the mass spectacle to form memories has been questioned, owing to the nature of modern social life. Edensor highlights that globalization and the fracturing of communities mean that scheduled, ritual performances are now encountered too infrequently to exert much effect. Instead, identities and memories persist through everyday, mundane practices of the individual, involving the material, spatial, and performative (Edensor 2002).

This study analyses the attempts of Imperial War Museum (IWM) North to challenge popular representations and memories of war through bodily encounters with architecture, space and objects. The use of architecture and objects for shaping memories has recently gained more attention within memory and museum studies (MacLeod et al. 2012), but their use in challenging memories that have assumed an almost sacred status is still unusual. The article which follows is divided into two main parts. The first focuses on the exhibition space, and the second examines the shop. In the first section, the architecture of IWM North and the use of affect and atmosphere to challenge memories are discussed. Despite their potential to overturn preconceptions, it is argued that the need to attract visitors means that spatial mediation and familiar object placement are used, which results in potentially difficult encounters being assimilated into everyday spatial experiences. Ultimately, this means that familiar historical narratives are reinforced and possibilities for critical reflection are largely avoided.

The focus of the second section is the museum shop. Museum shops have been neglected in academic research but they merit attention due to their increasing centrality and role in generating income. At IWM North, the shop atmosphere confirms popular ideas of war. This is done through the space itself, and the performance of familiar body techniques that it allows. Furthermore, the selling of souvenirs allows the museum to extend its impact on memory formation after the museum visit has ended.

The research for this study was carried out during 2012-13. It involved interviews with five key members of staff, each representing one strand of IWM North's work: education and learning, shop manager, exhibitions manager, shop buyer for IWM as a whole and IWM North's historian. ${ }^{1}$ Additional information came from listening to volunteers' accounts on an ad hoc basis, but the museum did not grant permission to interview members of the public, although observations of behaviour and remarks were made. Auto-ethnography was used though, in an attempt to personally understand the space. However, while this is a useful technique, caution must be exercised when using embodied sensory research in this way in order to avoid making generalisations concerning spatial experience (Paterson 2009). Detailed analyses of the architecture, and the ways in which space and exhibitions are laid out were undertaken. As 
a large part of the work discusses encounters with space, time was spent in various locations watching movement and interactions. As part of this, over 250 photographs were taken.

\title{
A Different Sort of Space
}

Buildings have long been designed so as to communicate meaning (Wischer 2012, Bloomer et al. 1977, Rasmussen 2001) but the idea has only been taken up by museums in recent decades. Rather than solely housing objects, museum buildings have evolved to become all-encompassing 'narrative environments', capable of communicating meaning through their materiality (MacLeod et al. 2012: ix). The potential for this can be understood through the concept of affect. Theories of affect have grown in recent years, arising out of a concern with lived human experience, rather than linguistic and representational theories that have long been the focus of social sciences (Thrift 2008). The affective turn, argues Hardt, is useful because it encourages a focus upon the body and emotions, as well as the mind and reason (Hardt 2007). Affect aids in understanding '... both our power to affect the world around us and our power to be affected by it' (Hardt 2007: ix). Affect can be surmised as the potential to act and it arises through the meeting of bodies, human or non-human. Seigworth and Gregg provide this useful description:

\begin{abstract}
Affect arises in the midst of inbetween-ness: in the capacities to act and be acted upon. Affect is an impingement or extrusion of a momentary or sometimes more sustained state of relation as well as the passage (and the duration of passage) of forces or intensities...Affect, at its most anthropomorphic is the name we give to those forces - visceral forces beneath, alongside or more generally other than conscious knowing, vital forces insisting beyond emotion - that can serve to drive us toward movement, toward thought and extension.... Indeed, affect is persistent proof of a body's never less than ongoing immersion in and among the world's obstinacies and rhythms, its refusals as much as its invitations (Seigworth and Gregg 2010: 1).
\end{abstract}

Affect, then, is the production of potential to act and think that is created through an encounter between bodies and things (Adey 2008, Pile 2010, Thrift 2004, Thrift 2008). Affect can lead to certain feelings and behaviour but the outcome is never guaranteed. As Hardt writes, 'We do not know in advance what a body can do, what a mind can think - what affects they are capable of' (Hardt, 2007: x). For the purposes of a study on museums, however, by combining space and objects in particular arrangements, certain behaviours and ways of thinking may be promoted.

Applying theories of affect to museums gives them a theatrical role in which the building is a set and the visitors partake as actors in a drama. Interaction between actors creates the space out of which affect rises and, in the context of the museum, this could stimulate reflexivity and memory formation. However, as Zumthor argues, the success of this depends upon the totality of atmosphere, with all elements functioning in harmony (Zumthor, 2010). Despite different approaches to notions of affect, a common strand is that of potential. The body is constantly involved in a process of movement and flux, as opposed to stasis. In this way it is always characterised by being 'not yet' (Seigworth and Gregg, 2010: 3). Anderson adds to this understanding, noting that atmospheres, understood as multiple bodies capable of affecting each other, are unstable. They are shifting and always in the process of becoming, being simultaneously 'indeterminate and determinate' (Anderson 2009: 78). Atmospheres then are never determinate but always remain unfinished because they are open to being taken up in individual, subjective experience (Anderson 2009).

IWM North, the creation of architect Daniel Libeskind, was underpinned by this desire to forge memories and reflection on the past through person-material interaction. Opened in 2002 in Salford Quays, Manchester, the museum building is composed of three 'shards' of a shattered globe, representing the three 'arenas' in which conflicts are played out: earth, air and water (figure 1). In contrast to the usual narratives concerning Britain and war, disruption was to be a constant theme. Libeskind contends that architecture must engage with painful memories, and space and materiality should evoke discomfort through encounters with them 
(Libeskind 2004). This is manifested in the complexity of form of IWM North, which contrasts with the traditional conception of the museum as providing an authoritative narrative of events (Bennett 1995). Rather than creating the possibility for acquiring a coherent narrative of war, Libeskind aimed to construct a space which would represent the impossibility of understanding war's brutality through its form.

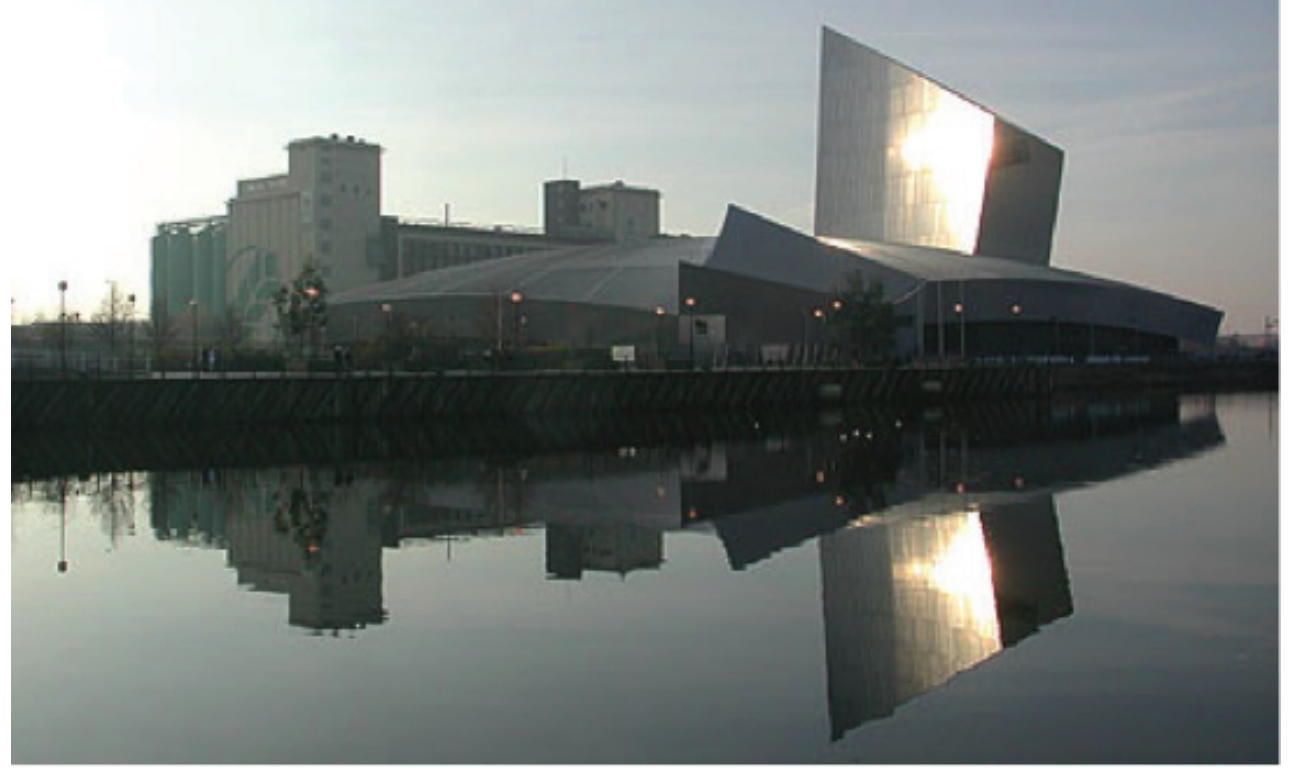

Fig 1. IWM North, pictured with the earth shard to the left, the air shard overlooking the water and the air shard extending upwards.

Understood through theories of affect, the structure and layout of buildings can contribute to the generation of certain feelings (Adey 2008). As Stewart writes, the whole world is full of 'bloom spaces', or environments and atmospheres out of which affect arises (Stewart 2010: $340)$. In this way, affect is unreflexive, yet it can lead to reflexive thought and behaviour, with the pre-cognitive and the cognitive self both playing a part in feelings and actions (Thrift 2008: 7). Libeskind's aim was to foster novel reflections on war, arising from an embodied encounter with the museum. This is first done through the outer surface of the museum. The imposing, steel-clad exterior is accentuated by its tiny entrance. As Zumthor contends, in architecture, tall, thin doors magnify the subject's sense of importance, while small, concealed doors create feelings of intimidation (Zumthor 2010: 51). On entry, the building explodes into a 95-foot high, batten-clad air shard. Visitors can take a lift to a viewing platform at the top of this shard, which is tilted 4.5 degrees, and this does create an unnerving sense of unease.

The contrast with the outside world is heightened inside. Museums have long been associated with coherent understandings and movement (Bennett 1995), yet here the space is difficult to anticipate. Tight, low-ceilinged corridors open out onto large spaces, and staircases are claustrophobically narrow. Handrails are not parallel with the floor, which itself is rough tarmacadam. Importing a surface used outside to the traditional space of a museum is disturbing and it is common to see people looking down. There are no right angles within the building and some corners form sharp, tapering angles. The ceilings are high, yet the space is dull. Illumination is provided by recessed, 'gash lighting', typical of Libeskind's architecture, but its inclusion here accentuates the idea of the shadows of war by leaving certain areas gloomy. This 
is intensified by the dark red and black walls. Colour is not neutral and red and black have long held negative connotations, being associated with anger and tension (Rasmussen 2001, Stone and English 1998: 176). Further to this, the exhibition space has no windows, permitting no trace of the external world. From entering the space, the floor slopes two metres. Staff can be observed reassuring visitors that this is intentional and the building is not unsound. In spite of this, some visitors look wary on entering and it is common to hear people say that they are lost or cannot see well because of the lighting. When first visiting the museum, I felt disorientated and the combined sensation of gloomy lighting and a sloping floor was disconcerting. While Tuan argues that architecture is concerned with creating order out of disorder (Tuan 1977), this deconstructivist architecture serves to reverse order to create a sense of dissonance.

The affect generated through dissonant architecture could be capable of prompting reflection because of these different spatial encounters. As Thrift argues, human experience is not stable because '...the human sensorium is constantly being re-invented as the body continually adds parts to itself' (Thrift 2008: 2). This means that buildings evolve and generate meanings through spatial performance (De Certeau 2002, Haldrup and Larsen 2006). The performance of space is a learned, embodied ability that occurs through a meeting of self and space. This is a multi-sensory ability, whereby the body interacts with its surroundings. Hawkins and Straughan note that this involves the participation of the whole body in its surroundings: 'To expand, touch here is a bodily doing of immersion, encroachment and infringement, encouraging an awareness of bodily limits and horizons' (Hawkins and Straughan 2014: 132). Paterson adds that this can be understood in terms of the 'haptic' or internally experienced bodily sensations, involving mind and body (Paterson 2009). Expanding on this, Mauss's expression 'body techniques' explains that people learn to use their bodies in space through social exposure, creating a bodily habitus (Mauss 1979). As the body is porous and is open to its environment, ways of living are learned through this constant interaction (Hawkins and Straughan, 2014). These interactions are felt externally by the body but also haptically, whereby the body experiences space and movement internally (Paterson 2009). While it is socially formed through such interactions, the habitus 'is man's first and most natural instrument', because of its continued, unreflexive formation (Mauss 1979: 104). It is generated through experience which then structures future action, without the need for conscious thought, unless disruptions occur. Clearly at IWM North the aim is to foster such disruptions through the design of the building, which is intended to upset everyday modes of interaction through the affect generated, and to provide an encounter that is alien to the habitus.

It is because of their disruptive effect on the habitus that these unusual spatial encounters could lead to changed thought (Thrift 2004). Anderson affirms that atmospheres are unstable and shifting and through bodily interaction, the potential for affect and reflection is stimulated (Anderson, 2009). Britain's military history is so often a source of unreflexive celebration, yet Libeskind was clear that the museum was to highlight war's impact and the difficulty in attaining peace (Russell 2002). The problems of exercising the body's habitus here could prompt feelings which refuse resolution, like experiences of conflict. The hope is that these would create the potential for new ways of thinking.

\section{Damage Limitation?}

Despite the aim of promoting critical reflection on conflict, such strategies present a problem for the museum which relies upon strong visitor numbers. This consideration has become more pronounced as national museums (including IWM) have received large funding cuts. ${ }^{2}$ While there is no guarantee that the discomfort of the architecture will be universally felt, it could stop visitors from making a return visit. Owing to this, the museum uses welcoming strategies so as to prevent discomfort. For example, daily orientation tours are provided to prevent visitors from feeling lost or uncomfortable. A member of the learning team explained this:

...every day we offer an introductory tour to the museum which lasts about 20 minutes...just giving a bit of background about the museum and helping visitors to find their way around. We run them because it provides an opportunity for visitors to find out more about the museum, particularly because of the style of the building... 
This quote reveals that these popular tours are provided so as to remove the sense of the unknown and dislocation that the space could create. This means that there is a smaller possibility of Libeskind's vision being realized, because of the mediating practices employed (Rose et al. 2010). Visitors are shown how to move around the building which means that understanding demands less bodily participation as directed action encourages a dwelling to which the habitus is accustomed. This was confirmed by the Exhibitions Manager:

\begin{abstract}
...for visitors [the building] presents challenges ...the challenges that they face, we try and, not counter, but help them work through how they're feeling so that's why we do free tours to explain about the building. Once you know it's purposeful - it sounds awful, "we purposefully want you to feel uncomfortable", but once we explain it they're like "ahh...", and they start to get it...
\end{abstract}

Libeskind intended the building to cause discomfort through an encounter with the unknown. Yet, by using tours that explain this, the unknown becomes known. As Skolnick highlights, powerful architectural encounters occur only through an environment that stimulates all the senses (Skolnick 2012). However, these tours remove the potential for the purely phenomenological, affective encounter. Despite being informed that the purpose is to make visitors feel uncomfortable, it is questionable whether visitors are capable of sensing this once they have been informed of the purpose.

This is intensified by further staff interaction. The first point of contact for visitors is the information desk, of which the shop manager noted:

...we're the first point of contact for people visiting the museum so we welcome visitors in... we provide them with all the information that they need for their visit, the daily floor plan...we've a map in there as well. The team's focus on really giving a brilliant welcome is absolutely just the highest priority.

This welcome means that disorientation is, again, unlikely to be realized. As soon as visitors enter, there are maps and friendly staff (the museum is heavily staffed by both paid and volunteer workers). These are normal features of museums but, in this context, it is another way of reintroducing familiarity. The shop manager added:

... [visitors] do value it... it is quite difficult to orientate yourself around this building. So the team are really good and they direct people...they really know things that people need...toilets, lockers, where the shop is, where's the café...

This comment reinforces that steps are taken to create a sense of ease and to re-establish normal body techniques. Adey notes, '...like water, atmospheric isolation is always subject to some little excesses, slippages and leakages' (Adey 2013: 305). By pointing out features such as toilets and the shop, around which everyday performances are ordered, embedding points for the habitus 'leak' back into the atmosphere and are made obvious. An unwelcoming atmosphere becomes more normal by showing that common environments are to be found here.

Visitors are frequently reminded to ask for help from the staff situated at the entrance to the exhibition space. Jim Forrester, former branch director, noted at the time of opening that a conscious decision was made to invoke the emotions through the architecture, challenging visitors to be jolted out of their comfort zone and to ask difficult questions (Russell 2002). However, it is hard to find evidence of this. The exhibitions manager added,

...our welcome has to be really, really nice, people have to be friendly because you're not just walking into a building that's giving you an experience that you're not used to...you're walking into a building you're not used to... So we have lots of volunteers out in the galleries, making it clear that if you're uncomfortable, if you want to talk about anything... please, you know, go and speak to a member of staff, even if it's going, "I'm really upset about that," that's fine. "We'll find you a seat...do you want me to take you to the café?...Did you want some fresh air?" Just something so that they feel comfortable and they're not experiencing something that really knocks them for six and has just left them low. 
This quote highlights that the relationship between the unknown of the building and the encounter it could provoke is recognised. Help is explicitly offered because of this, in order to diminish the affect of the building and reaffirm the bodily habitus.

In addition to spatial mediation, objects are mobilised in order to reaffirm a familiar historical narrative. Traditionally the focus of museums, the use of objects is now being questioned and digital media has been suggested as better suited to transmitting stories (Cummings and Lewandowska 2000, Conn 2010, Tallon and Walker 2008). IWM North does employ digital technologies, most notably 'The Big Picture Show', in which films of aspects of war are projected onto the walls. However, objects continue to play a fundamental role, namely in their ability to create a narrative. Objects are chosen based on the contribution that they can make to a story. This was confirmed by the exhibitions manager who said, 'You know, if you have a medical kit that's just a wooden box, is that wooden box really going to tell the story if we can't have it open?' The story is furthered through the sequence in which the objects are placed. This matters because meaning is generated through the fusion of self and object. To walk through a museum is to walk in harmony with the exhibits and perform their history (Bennett 1995). Despite the confusion that Libeskind wished to create through the chaotic space, objects in IWM North are placed in a chronological narrative of war that lines the perimeter wall. Visitors are advised to follow this narrative, to avoid getting lost both physically and in the narrative of war. This allows an easy navigation of an otherwise difficult building, and the reaffirmation of a familiar narrative of events.

The individual objects on display contribute to the atmosphere of familiarity. These include easily recognizable military uniforms, weapons and Home Front articles. While connected to horrific conflicts, these objects provide concrete proof of a well-known narrative of the past. IWM's historian noted that the objects chosen for display are those which visitors find 'fascinating', 'moving' and can 'engage with'. Objects presented must be able to communicate something and bring meaning to the visitor. They must not have the potential to be alienating.

Deeper connections are encouraged through opportunities to touch objects. Pallasmaa criticises the priority given to the sense of vision in modernity and instead argues that it is touch that allows experiences of the world to be fully integrated with the self (Pallasmaa 2011). Touch is the way that the hands 'see' and deeper understandings of life are formed (Pallasmaa 2012). In contrast to glass casing, object-handling sessions at IWM North allow integration and enhance the potential for an embodied experience. A member of the education team explained that handling provides a 'sense of connection... it might be something that's really familiar, and it adds to their experience.' This confirms Hawkins and Straughan's argument that touch possesses a very strong affective capacity because it has 'an attunement to the movement of molecules outside of an organism's body, detected by the body as molecular vibrations...' (Hawkins and Straughan 2014: 136).

This connectivity is reinforced by the specific objects that can be touched. During one visit, the tray of objects on offer was related to the First World War (figure 2). Items such as grenades aroused little comment from visitors, but the objects that provoked the most discussion were postcards, and comparisons were made with postcards available today. When ammunition shells were passed around, some visitors started to discuss their contemporary uses, such as housing fire pokers and other household items. This connection between the past and the present through touch again provides the habitus with a further rooting. Even ammunition shells were rendered familiar because their contemporary appropriation was discussed. This accessibility allows war to be made safe and accessible because its objects are made part of a familiar material world. Object handling can therefore be said to serve a similar function to guided tours. As the objects are selected and presented within a certain familiar narrative, the past that is brought into the present is a safe one. While the museum slogan is 'Shaped by War', such experiences demonstrate again that the museum shapes memories through links to the familiar. 


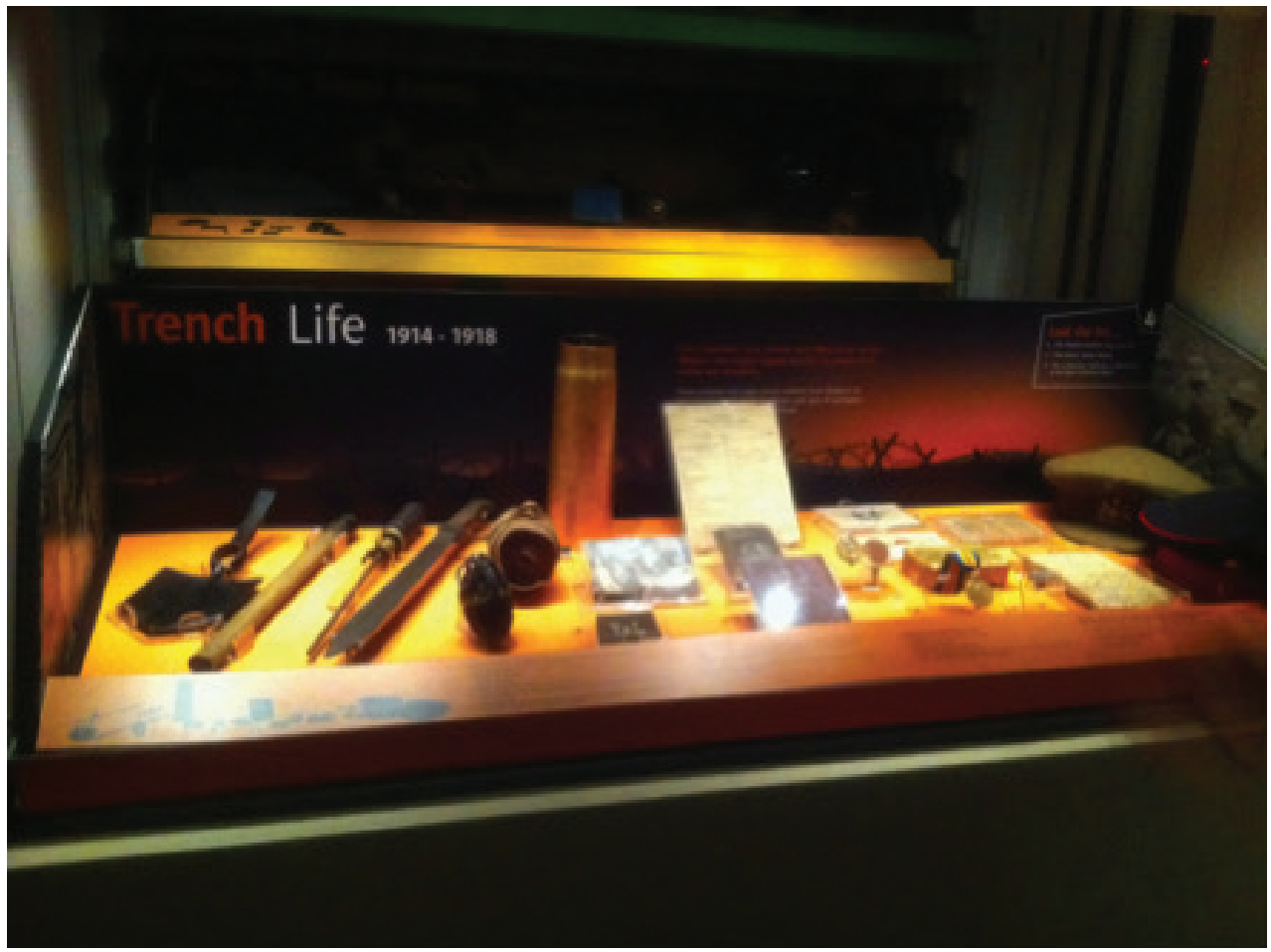

Fig 2. One of the Time Stack machines, open for the objects to be handled. Unusual objects such as ammunition are included but most popular are the letters home and the postcards in the centre.

\section{The Museum Shop}

The main exhibition space falls short of achieving Libeskind's aims because mediation and objects allow a stable performance of both the bodily habitus and a familiar historical narrative. The shop heightens this. Financial needs mean that museums today increasingly promote event hosting, and house amenities such as shops and cafés. Yet these aspects have long been ignored by academics. However, their prominent placement means that they should be examined as spaces which can also affect understandings of the past.

As noted, new experiences of architecture are measured through the body's habitus (Pallasmaa 2012). Space is therefore an experience of both past and present. In IWM North, the exhibition space has the potential to disturb the habitus because of the affect generated through new spatial and material interactions. These are markedly different to those formed outside the museum, where such atmospheric interactions are today largely based on ideas of comfort. For Bachelard, it is the home that moulds formative, comfortable experiences of place, because of the time spent there and the rootedness with which it is associated; homeliness and familiarity then become benchmarks for future experiences of place (Bachelard 1994). Comfort can be derived from being rooted in places associated with prior experiences of satisfaction. Conversely, security is disturbed in places of disjuncture (Bachelard 1994).

Notwithstanding the obvious criticism that, for some, home is not a happy place (Moore 2000 , Mallet 2004), increased mobility and globalization have altered the relationship of self to place since Bachelard was writing in the 1950s. This has not removed desires for security, but globalization and increased mobility have led to individuals spending less time rooted to one place. Yet alongside this there has been a standardization of global environments, most notably those connected to consumption (Creswell 2004, Thrift 2006, Bauman 2000). While this has attracted criticism (Cresswell 2004), standardization can be experienced positively. Similarities 
between spaces of consumption permit a temporary and comfortable rooting in any place. Germann Molz employs the term 'global abode', to suggest that 'home' should encompass, not just places of similarity, but also an ability to perform homeliness (Germann Molz 2008: 327). Similar universal experiences (such as visiting shopping spaces with comparable layouts) mean that homeliness can exist in a physical space, but can also be performed. Rather than being dislocating, this standardization allows repeated consumption practices, which become familiar practices of the self and contribute to the body's habitus (Paterson 2006). Shops have increasingly come to form familiar spaces, allowing the transposition of learnt modes of moving, seeing and touching (Mauss 1979).

Museum shops are now pivotal in generating income and so the shop environment must promote spending. This is not peculiar to IWM North; the barriers separating museums and shops have been broken down in recent years by the abolition of entry charges, which has located museums as places for browsing. Moreover, museums are now places for entertainment and the generation of money through the selling of heritage, as well as education (Hewison 1987). According to the shop manager at IWM North:

People in museums are realising more that shops are really important and that actually money isn't a dirty word and we need to generate a big amount of our income ...some people assume that museums get nearly all their money from the government which absolutely isn't the case.

These financial realities mean that museum shops have had to adopt an overtly consumerist mentality. The buying manager for IWM added:

...the professionalism of the shops has changed... by the very nature of somebody like me being employed who comes from a retail background... getting expertise from the high street and bringing it into the heritage world.

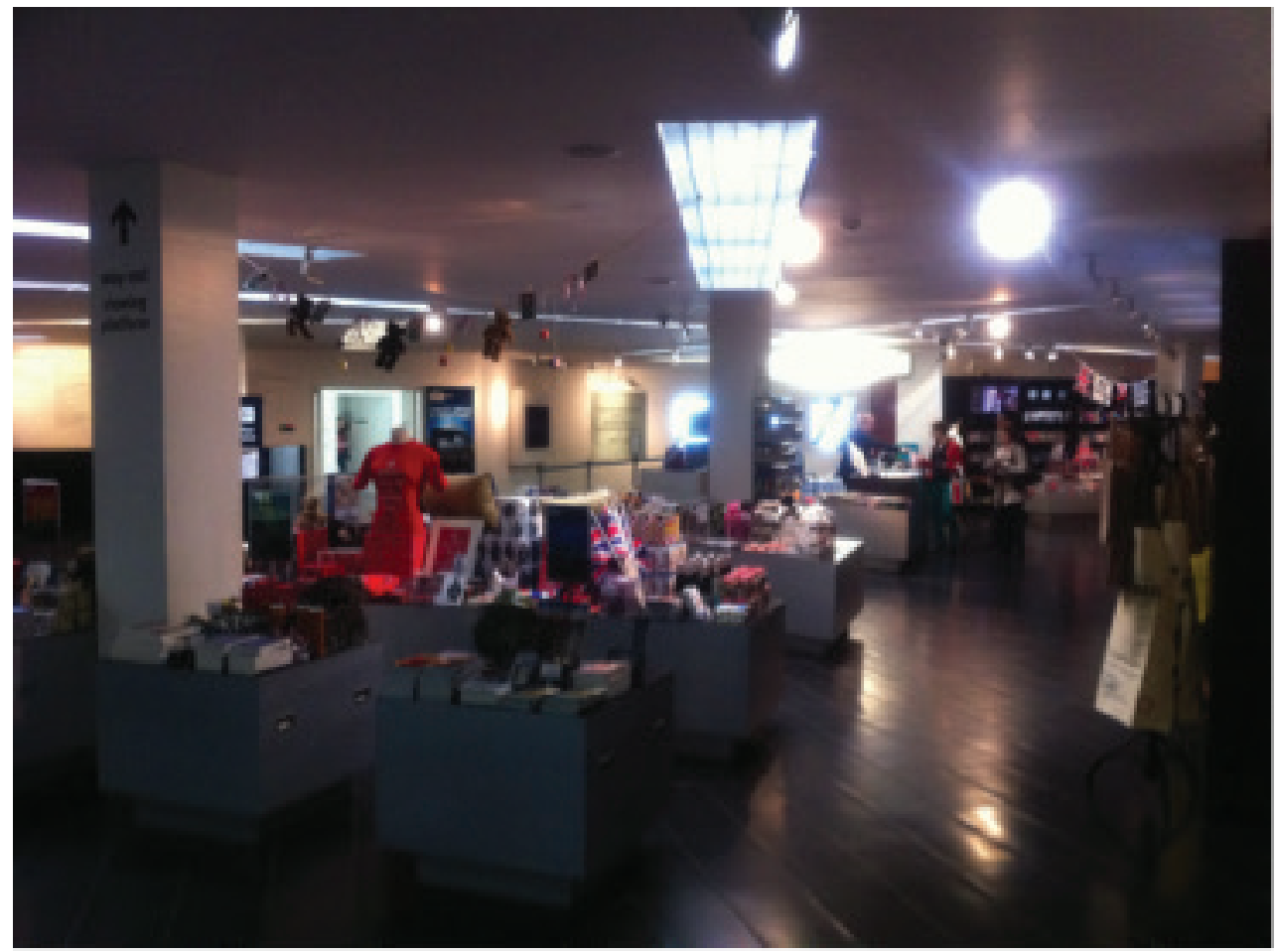

Fig 3. Clear, light, open space forms the shop. The exterior of the museum is just visible at the end. 
Staff are clearly aware of the need to mimic and absorb mainstream consumption principles, using staff with experience of that sector to give museum shops a professional edge. However, in the context of IWM North, mimicking the high street, when contrasted with an exhibition space that aims to create disorientation, immediately locates the shop as a refuge. It is a 'global abode' because it reassures and provides familiarity for the habitus. The staff recognise that visitors expect to find a shop in the museum and that it is a part of the museum experience. As planned retail space is now a normal feature of public life, the presence of a shop returns visitors to daily experiences, fulfilling the expectations contained within the notion of 'the visitor experience'.

The shop also counters the rupture of the main exhibition space by aping the characteristics of other shops. It is immediately welcoming by being open and light, without exterior walls or doors. The museum entrance and external light are visible, providing the 'restorative function' that is impossible in the exhibition (Stone and English 1998: 176). The ability to see outside also provides a reminder of a connection to the everyday. Reds and blacks have been exchanged for bright white walls, while the floor is smooth tiles. Instead of high walls and awkward angles, low-level displays allow a full and complete survey of the shop (figure 3).

Taken together this forms part of a deliberate strategy to encourage shopping. The shop manager noted:

In terms of retail principles, you need it to be a well-lit space really to work and to make it inviting so people can see properly what they're actually looking at and trying to buy.

By adhering to common retail principles, the shopping space bears a deliberate similarity to everyday consumer spaces. Adey writes that there is now a '...rising politics of sensibility premised on atmospheric comfort' (Adey 2013: 301). This is shown in the comfortable atmosphere of shopping spaces that has been incorporated here. These principles stand in complete opposition to those envisioned by Libeskind. Allowing the visitor to feel in control represents the opposite of Libeskind's desire for visitors to be in a building of disruption. There is little need to be reflexive as everything is presented for easy, pleasurable consumption, without help being required.

As in the exhibition space, creating an agreeable atmosphere involves object arrangement, to encourage certain encounters and feelings (Hetherington 1997). The shop manager notes:

So if you were to look in the shop, we try to make everything so it's nice and clear, it's not messy. If you look, there's quite a lot of blocks in the way that we merchandise, just so it makes it really, just strong and bold. You know, the stock level needs to be just right, so not too little and not too much because you don't want towers of things falling over.

It is a deliberate strategy that nothing should appear 'messy'. This contrasts with Libeskind's ideas on the chaos of war. Stock levels are carefully calculated so there is no danger of anything falling over and nothing is 'too little' or 'too much'. Libeskind conceptualises war as something that refuses comprehension, as reflected in his use of angular spaces and dark corners that embody war's messiness. Yet bricolage within the shop can be approached in safety because everything is 'nice and clear'. This can have a powerful impact on the creation of memories because space is produced through movement (de Certeau 2002; Germann Molz 2012). The 'global abode' is achieved, not only through places being similar in design but through transposable enactments that allow familiar space to be performed (Germann Molz 2008). The shop permits the recognizable world of consumption to leak into the unfamiliar because known modes of performance can be repeated, but in the historical and authoritative context of the museum space.

This is complemented by the easily recognizable historical atmosphere within the shop. There are cues which affirm popular historical concepts with which visitors are already familiar. Strains of 'We'll Meet Again' and 'The White Cliffs of Dover' can be heard over the speakers, mechanical Spitfires whizz around on strings and cheery propaganda posters cover the walls. A mannequin dressed heroically in a flying outfit and retro board games contribute 
to what Paterson terms 'atmospherics', influencing consumer behaviour through the creation of a certain atmosphere (Paterson 2006: 149). But more than just promoting spending, these elements function holistically to create a 'mood'. This mood is one which resonates with popular understandings of the past, achieved in a familiar consumer environment.

Specific object placement also contributes to this mood. IWM's buyer noted that prominent placement is afforded to items that sell well and likewise, prominent placement causes products to sell well. Staff spend time observing consumer flows, to understand patterns of walking and the areas most visited. This can then be used to maximise sales. The objects which occupy these prime positions conform to the historical climate formed outside the museum. In general these are associated with the Home Front. Such items do not require an exact historical knowledge of Britain's history but can be easily encountered because 'banal nationalism', as discussed earlier, is formed through everyday encounters (Billig 1995). By incorporating such ideas into the material fabric of the shop, a reaffirmation of identity is permitted.

The shop sells the standard fare of museum goods, such as key rings, pens and magnets. However, the majority of the stock is composed of items inspired by images of war, in particular World War Two, despite the museum remit being 1914 to the present day. This is a conflict that is both familiar in popular culture, and one that evokes pleasant memories. Typical fare can be described as 'kitsch', festooned with iconic images of Churchill or propaganda reproductions. The buying manager discussed the reasoning behind stocking such goods.

It's reassuring.... it reminds people of things they've seen...generally in the market there's a nostalgia around...it's reassuring to look back to what is considered a better time, or a time where they had different values...

While kitsch has been the target of academic scorn, its formulaic repetition can provide reassurance (Binkley 2000). The staff recognise that its use permits material routine and security. It requires little reflexivity because it is a reproduction, both of a mass product but also of an embodiment of ideas and mentalities. This allows it to reaffirm that which has gone before.

What is being sold therefore is a selective version of war. Just as the shop space is arranged so as to be easily navigable, the same principle is embodied in the selling of the souvenirs. The effect of this is to create the potential for an experience of war that is controlled and predictable. The trials of rationing and landscapes of the dead are absent but popular gift ranges include fudge and teddies (figure 4). While these are given a loose connection to conflict (the fudge is labelled 'ration fudge' and the bears wear soldier uniforms), this is measured; teddies and sweets speak of comfort. Moreover, these are items that are easily appropriated for sale in any museum. Bears and fudge have no real relation to war, nor any museum subject, but they are sold in most museum shops because they sell well. The ubiquity of such items adds another layer of familiarity, despite the subject with which it is concerned. But souvenirs are circumscribed in their materiality and representations. This means that they in turn can also circumscribe certain encounters and deeper, potentially difficult, reflections.

The omission of some souvenirs contributes to an exclusion of certain events from popular memory. When questioned about the decision to focus primarily on the 1940s and, especially, to sell little to do with more recent conflicts, the shop manager said:

Some exhibitions... are quite serious, they don't necessarily lend themselves to products...you need to be careful to not trivialise anything really... if you were looking at a more gift-based product, you know, for the Falklands, I don't know what that would be...

The implication here is that some parts of war are suitable to market, while others are not. The parts of war that lend themselves to marketing are those which are already well-assimilated into the British psyche and will not disturb this in their representations.

Selling souvenirs can potentially exert a greater impact than just a visit to the museum because souvenirs can be taken home. Being able to touch objects in a museum allows for a sense of control but, when the objects enter into ownership, this level of control is deepened. While model tanks and planes represent destruction, the ability to grasp a miniature gives the subject control of the world through possession (Bachelard 1994). Toys, and the past encapsulated within them, can thus be made alive, but in a measured way. If used to re-enact 
war, for example, in children's games, the outcome is never uncertain. Moreover, all souvenirs are intended to be taken home. As Dant contends, the life of an object goes far beyond the moment of consumption (Dant 1999). This means that a souvenir can extend the influence of the museum. The shop manager noted, 'You expect to go to a museum shop and find an apron and a tea towel...nice souvenirs from that day but based on the collections which is really great...' Here, tea towels and aprons are singled out as providing a reminder of the museum but, by their nature, domestic items (which are among the most common items sold) allow an easy insertion into the atmosphere of daily life, and a merging of the visit with the familiarity of home.

This is important for forming memories because placing objects in the home further domesticates them so that any otherness is removed (Edensor 2002). An apron with a reproduction of a rationing poster reminds the wearer of war but, by being placed in a safe environment of Western abundance (and certainly not one afflicted by the privations of rationing), connections to hardship are removed. Josipovici argues in this respect, when an object is interacted with regularly, the punctum, that part of its being which makes the subject stop and think because it does not assimilate into everyday life, is removed (Josipovici 2006). It becomes incorporated into the habitus. Such souvenirs make memories of war easily approached. They do not lie but they embody selective truths and, when

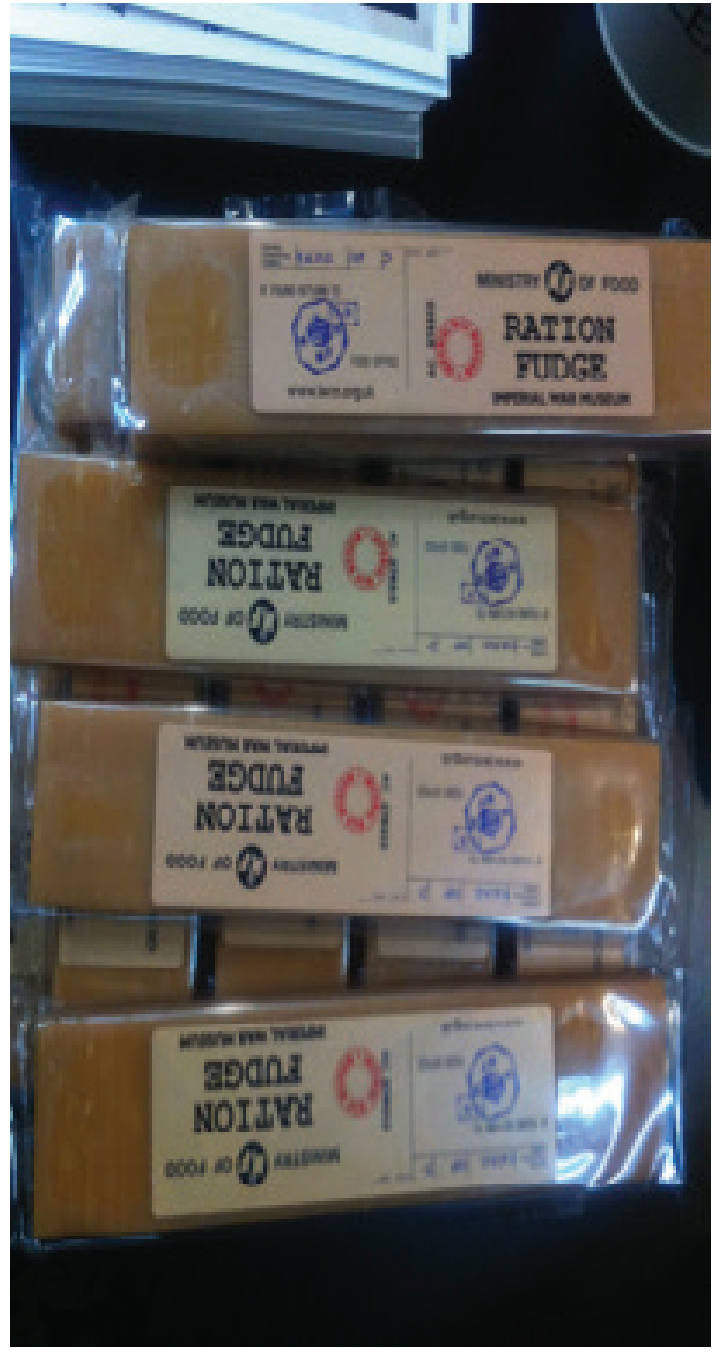

Fig 4. Fudge and teddies are among just some of the pleasant items that fill the shop. comfortably encountered each day, these truths can become happy metaphors for war as a whole.

\section{Conclusion}

This research contributes to studies on the use of architecture and objects to generate affect within museums. However, the study also verifies Zumthor's argument that affect and atmospheres need to be total in order to succeed. At IWM North, the architecture and exhibition space envisioned by Libeskind show promise but staff and object mediation instead allow for the familiar to be powerfully reaffirmed. The affect created is diminished and the reinsertion of familiarity and comfort prevent the need for mental reflection because the habitus of the body is not challenged.

This is most obvious in the shop. Designed to mimic everyday spaces of consumption, it re-establishes a space of normality in the museum. This is complemented by the ordering of objects, which themselves embody familiar historical narratives and limit the possibilities for 
a more critical analysis of war. By being taken home, these souvenirs extend the visit but in a selective way, encouraging certain lines of thought while constraining others. As museums are required to become increasingly self-financing, shops and sales are ever more vital. Their centrality in the building, and their role in the museum experience mean that shops should be afforded as much priority as exhibitions in museum studies. They too offer encounters which can stimulate ideas on the past. By selling souvenirs, this can endure long after the museum visit is over.

One final point to be considered is the potential ethical implication of this. World War One has largely fallen out of living memory and few survivors of World War Two remain. Memories therefore increasingly require material mediation (Nora 1989, Gillis 1994). However, unchanging materialities can contribute to banal nationalism and lead down narrow paths of thought concerning both the past and the present, and affect how war is perceived today. Buying items associated with British victories and the Home Front may seem like small, individual acts, but such regular encounters which tie into experiences of the everyday are potent. A limited number of narratives are available to buy in the museum shop and these objects endure and become things to think with. This means that the scale of their effect should not be underestimated. Shopping practices and the ownership of memorabilia may appear banal, but banal does not mean unimportant, or benign. Indeed, the banal is potentially more dangerous because it is so insidious (Billig 1995).

Narratives and objects which present war as an adventure, or as a time when the best qualities of the nation are exposed, can stifle contemporary critical reflection on the negative aspects of conflict, or engagement with its deeper causes. Holding onto what are seen as the positive parts of a military past can create essentialist perceptions that identities and circumstances have not changed. For example, Robin Wilson speculates that the obsession with the 1940s has hampered relations with Europe. Instead of recognising the deaths of millions and the necessity of allying with other nations, Britain maintains the illusion of the small, yet great island, fighting alone (Wilson 2012). Museums and material objects too are capable of promoting such mentalities because they are static and so can embed an unambiguous sense of the past, preserved from the ravages of time.

War is not possible without popular endorsement or at a minimum, a lack of resistance amongst the public. This tends to be achieved through a selective framing of conflict (Butler 2010). Museums and objects play a part in this. War is often accepted, or at least tolerated in Britain because national worth is founded upon notions of victory in conflict. Yet the darker side of this is that such mentalities endure and some lives come to be viewed as worth more than others (Butler 2006). In IWM North, the selective representations could work to prevent deeper reflections, or criticisms of conflict. That this occurs through the material experiences discussed in this paper is conjectural. As affect is a state of potential, it can be refused. This has not been covered here but it would certainly merit further research. However, space and objects do serve to encourage certain relationships and understandings through the body (Adey 2008). With the knowledge of what visitors encounter at IWM North, along with theories on popular understandings of war, the likelihood of this happening is something which deserves serious academic engagement.

Received: 15 April 2014

Finally accepted 30 June 2015

\section{Notes}

1 Only job titles are referred to throughout this text. As agreed with the interviewees, all personal names have been excluded for anonymity.

2 IWM receives less than $50 \%$ of its funding from the government. Furthermore, the Department for Media, Culture and Sport aimed to cut its budget by $25 \%$ by 2014 . As part of this, IWM has received a $15 \%$ funding cut, yet is still expected to maintain free entry, protect its collections, but generate more income through private donations and spending. See Hunt, J. (2010) 'Letter from DCMS to IWM, c/o Sir P. Squire'. 


\section{References}

Adey, P. (2008) 'Airports, mobility and the calculative architecture of affective control', Geoforum, 39, 438-51.

(2013) 'Air/Atmospheres of the Megacity', Theory, Culture and Society, 30 (7/8), 291-308.

Anderson, B. (1991) Imagined Communities. Reflections on the Origin and Spread of Nationalism, London: Verso.

Anderson, B. (2009) 'Affective Atmospheres', Emotion, Space and Society, 2, 77-81.

Bachelard, G. (1994) The Poetics of Space, Boston: Beacon Press.

Barthes, R. (1993) Camera Lucida, London: Vintage.

Bennett, T. (1995) The Birth of the Museum. History, Theory, Politics, London: Routledge.

Billig, M. (1995) Banal Nationalism, London: Sage.

Binkley, S. (2000) 'Kitsch as a repetitive system: a problem for the theory of taste hierarchy', Journal of Material Culture, 5 (2), 131-50.

Bloomer, J. et al. (1977) Body, Memory, and Architecture, New Haven: Yale University Press.

Butler, J. (2006) Precarious Life. The Powers of Mourning and Violence, London: Verso.

(2010) Frames of War. When is Life Grievable?, London: Verso.

Calder, A. (1992) The Myth of the Blitz, London: Pimlico.

(1995) 'Britain's Good War', History Today, 45 (5), 55-61.

Connelly, M. (2004) We Can Take It! Britain and the Memory of the Second World War, London: Pearson.

Conn, S. (2010) Do Museums Still Need Objects?, Philadelphia: University of Pennsylvania Press.

Connerton, P. (1999) How Societies Remember, Cambridge: Cambridge University Press.

Cresswell, T. (2004) Place. A Short Introduction, Oxford: Blackwell.

Cummings, N. and Lewandowska, M. (2000) The Value of Things, Basel: Birkhäuser.

Daily Mail (2012) 'Ryanair's money grabbing rip-offs bring out our Dunkirk Spirit', http:// www.dailymail.co.uk/debate/article-2045648/Ryanairs-money-grabbing-rip-offs-bringDunkirk-spirit.html, accessed 25 April 2012.

Dant, T. (1999) Material Culture in the Social World. Values, Activities, Lifestyles, Buckingham: Open University Press.

De Certeau, M. (2002) The Practice of Everyday Life, Berkeley: University of California Press.

Edensor, T. (2002) National Identity, Popular Culture and Everyday Life, Oxford: Berg. 
Edwards, E. (1999) 'Photographs as objects of memory', in Kwimt, M., Breward, C. and Aynsley, J. (eds.) Material Memories. Design and Evocation, 221-336, Oxford: Berg.

Germann Molz, J. (2008) 'Global abode: home and mobility in narratives of round-the-world travel', Space and Culture, 11 (4), 325-42.

(2012) Travel Connections. Tourism, Technology and Togetherness in a Mobile World, London: Routledge.

Gillis, J. R. (1994) 'Introduction: memory and identity. The history of a relationship', in Gillis, J. R. (ed.) Commemorations. The Politics of National Identity, 3-26, Princeton: Princeton University Press.

Haldrup, M. and Larsen, J. (2006) 'Material cultures of tourism', Leisure Studies, 25 (3), 275-89.

Hardt, M. (2007) 'Foreword', in Ticineto Clough, P. and Halley, J. (eds.) The Affective Turn. Theorizing the Social, ix-xii, Durham NC: Duke University Press.

Harman, N. (1980) Dunkirk. The Necessary Myth, London: Hodder and Stoughton.

Harrisson, T. (1976) Living Through the Blitz, London: Collins.

Hawkins, H. and Straughan, E. R. (2014) 'Nano-art, dynamic matter and the sight/sound of touch', Geoforum, 51, 130-139.

Herf, J. (1997) Divided Memory. The Nazi Past in the Two Germanys, Cambridge MA: Harvard University Press.

Hetherington, K. (1997) 'In place of geometry: the materiality of place', in Hetherington, K. and Munro, R. (eds.) Ideas of Difference: Social Spaces and the Division of Labour, 183-199, Oxford: Blackwell.

Hewison, R. (1987) The Heritage Industry. Britain in a Climate of Decline, London: Methuen.

Josipovici, G. (1996) Touch, New Haven: Yale University Press.

Kuhn, A. (2002) Family Secrets: Acts of Memory and Imagination, London: Verso.

Libeskind, D. (2004) Breaking Ground. Adventures in Life and Architecture, London: John Murray.

MacLeod, S.; Hourston Hanks, L. and Hale, J. (2012) 'Introduction: museum making. The place of narrative', in MacLeod, S.; Hourston Hanks, L. and Hale, J. (eds) Museum Making. Narratives, Architectures, Exhibitions, xix-xxiii, London: Routledge.

Mallet, S. (2004) 'Understanding home: a critical review of the literature', Sociological Review, 52 (1), 62-89.

Mauss, M. (1979) 'Body Techniques', in Sociology and Psychology Essays, London: Routledge and Kegan Paul.

Moeller, R. (2003) War Stories. The Search for a Usable Past in the Federal Republic of Germany, Berkeley: University of California Press.

Moore, J. (2000) 'Placing home in context', Journal of Environmental Psychology, 20: 20717.

Niven, B. (ed.) (2006) Germans as Victims, Basingstoke: Palgrave. 
Noakes, L. (1998) War and the British. Gender, Memory and National Identity, London: I. B. Tauris.

Nora, P. (1989) 'Between memory and history: Les Lieux de mémoire', Representations, 26, 7-24.

The Observer (2012) 'Brown: we need the Dunkirk Spirit in 2009', http://www.guardian. co.uk/politics/2008/dec/28/economic-policy-gordon-brown, accessed 25 April 2012.

Pallasmaa, J. (2011) The Eyes of the Skin. Architecture and the Senses, Chichester: Wiley.

(2012) The Thinking Hand. Existential and Embodied Wisdom in Architecture, Chichester: Wiley.

Paterson, M. (2006) Consumption and Everyday Life, Abingdon: Routledge.

(2009), 'Haptic geographies: ethnography, haptic knowledges and sensuous dispositions', Progress in Human Geography, 33 (6), 766-788.

Pile, S. (2010) 'Emotions and affect in recent human geography', Transactions of the Institute of British Geographers, 35 (1), 5-20.

Rasmussen, S. E. [1959] (2001) Experiencing Architecture, Cambridge MA: MIT Press.

Rose, G., Degan, M. and Basdas, B. (2010) 'More on "big things": building events and feelings', Transactions of the Institute of British Geographers, 35 (3), 334-349.

Russell, J. S. (2002) 'Criticism with the Imperial War Museum North, Daniel Libeskind builds his case for a major museum destination on a budget', Architectural Record, 190 (10), 124.

Seigworth, G. J. and Gregg, M. (2010) 'An Inventory of Shimmers', in Gregg, M. and Seigworth, G. J. (eds.) The Affect Theory Reader, 1-28, Durham NC: Duke University Press.

Skolnick, L. H. (2012) 'Beyond narrative. Designing epiphanies', in MacLeod, S., Hourston Hanks, L. and Hale, J. (eds.) Museum Making. Narratives, Architectures, Exhibitions, 83-94, London: Routledge.

Smith, M. (2000) Britain and 1940: History, Myth and Popular Memory, London: Routledge.

Stewart, K. (2010) 'Afterword', in Gregg, M. and Seigworth, G. J. (eds.) The Affect Theory Reader, 399-354, Durham NC: Duke University Press.

Stone N. J. and English, A. J. (1998) 'Task type, posters, and workspace colour on mood, satisfaction and performance', Journal of Environmental Psychology, 18 (2), 175185.

Tallon, L. and Walker, K. (2008) Digital Technologies and the Museum Experience: Handheld Guides and Other Media, New York: AltaMira.

Thrift, N. (2004) 'Intensities of feeling: towards a spatial politics of affect', Geografiska Annaler, 86 B, 57-78.

(2006) 'Space', Theory Culture and Society, 23 (2-3), 139-46.

(2008) Non-Representational Theory: SpacePolitics/Affect, London: Routledge. 
Tuan, Y. F. (1977) Space and Place. The Perspective of Experience, Minneapolis: University of Minnesota Press.

Wilson, R. (2012) 'Not so splendid isolation: the UK and the EU', Social Journal Europe, http://www.social-europe.eu/2012/04/not-so-splendid-isolation-the-uk-and-the-eu, accessed 25 April 2012.

Wischer, S. A. (2012) 'Narrative transformations and the architectural artefact', in MacLeod, S., Hourston Hanks, L. and Hale, J. (eds.) Museum Making. Narratives, Architectures, Exhibitions, 132-143, London: Routledge.

Zumthor, P. (2010) Atmospheres. Architectural Environments, Surrounding Objects, Basel: Birkhäuser.

*Angela Loxham is an Economic and Social Research Council 1+3 PhD Student in the Department of Sociology, Lancaster University, UK. Her current research focuses primarily on the tactile sense and the development of this as a bodily habit in domestic and consumer environments of the nineteenth century. She is also interested in the use of space and materiality in museums and public spaces for changing bodily conduct, both in historical and contemporary contexts. She has published work in several journals including, Journal of Historical Sociology, Journal of Macromarketing and Textile History (forthcoming).

Email: a.loxham@lancaster.ac.uk

or aloxham@hotmail.co.uk 